\title{
MÔI TRỪ̛̀NG TRẦM TÍCH CHÂU THỔ VÀ ĐÁ CÁT KẾT CHỨA DẦU KHÍ BỂ NAM CÔN SƠN
}

\author{
Trần Khắc Tân', Ngô Thường San', Nguyễn Mạnh Toán', Phạm Hải Đăng², Hoàng Thị Thu Trang²', Trần Thọ² \\ 'Hội Dầu khí Việt Nam \\ 2Tổng công ty Thăm dò Khai thác Dầu khí \\ Email: tantk2016@gmail.com \\ https://doi.org/10.47800/PVJ.2021.09-02
}

\section{Tóm tắt}

Đường bờ biển là đới chuyển tiếp giữa môi trường trầm tích lục địa và môi trường trầm tích biển. Khu vực này chịu tác động của cả lục địa và biển. Châu thổ ven biển là kết quả quá trình trầm tích ở cửa các hệ thống sông; hình thái, địa tầng của châu thổ phụ thuộc vào các yếu tố khác nhau như trầm tích từ các sông vận chuyển đến, khu vực tiêu nước, hình thể địa hình dòng chảy vận chuyển ra biển và các yếu tố tác động của biển tái phân bố lại các vật liệu trầm tích ở đường bờ. Ngoài ra, vật liệu trầm tích còn có thể được cung cấp đến các đới ven biển dọc theo bờ từ nguồn ngoài khơi, không liên quan đến sông ngòi.

Các loại đá cát kết trầm tích môi trường châu thổ là đá chứa dầu khí chính trong địa tầng trầm tích ở nhiều nơi trên thế giới.

Có 4 kiểu tướng và môi trường trầm tích được minh giải theo mẫu và biểu đồ vật lý giếng khoan ở các giếng khoan Lô $07 / 03$ và Lô 04-1, bể Nam Côn Sơn. Các tướng này được mô tả tuần tự là đồng bằng châu thổ (delta plain), trước châu thổ (delta front), đồng bằng ven biển và tiền châu thổ (pro-delta).

Từ khóa: Môi trường trầm tích, đá cát kết, bể Nam Côn Sơn.

\section{Giới thiệu}

Tướng trầm tích châu thổ được tạo nên từ sự tương tác các quá trình động lực học như sóng, chế độ thủy triều, dòng chảy, khí hậu... làm thay đổi và phân tán vụn lục nguyên do sông vận chuyển. Thuật ngữ "châu thổ" (delta) lần đầu tiên được Herodotus (Thụy Sĩ) sử dụng khi quan sát bề mặt tam giác châu của sông Nile gồm phần châu thổ quan sát được trên đất liền và phần dưới mặt nước biển do sông vận chuyển đến. Do tác động mạnh mẽ của sóng và thủy triều mạnh hơn năng lượng vận chuyển của sông nên các trầm tích châu thổ có cấu trúc khá đặc trưng cho các môi trường khác nhau như: trầm tích của lòng sông nhánh, các đập chắn cát cửa sông, các hồ lục địa, đồng bằng thủy triều, các đụn cát, bãi biển, đầm lầy sú vẹt, đồng bằng muối.

Để hiểu và ứng dụng các mô hình trầm tích lục nguyên trong hệ thống châu thổ, nhóm tác giả trình bày quá trình

Ngày nhận bài: 7/8/2020. Ngày phản biện đánh giá và sửa chữa: 7/8/2020-20/6/2021. Ngày bài báo được duyệt đăng: 14/9/2021. hình thành châu thổ, các yếu tố chi phối trầm tích và tướng đá theo không gian và thời gian trên cơ sở phân tích dữ liệu các giếng khoan thăm dò Lô 04-1 và Lô 07/03 bể Nam Côn Sơn, phục vụ công tác liên kết các vỉa cát chứa dầu và chạy mô hình đánh giá trữ lượng trong hoạt động tìm kiếm thăm dò.

\section{Quá trình hình thành châu thổ}

Đới ven biển là khu vực giữa đất liền và đại dương, mang tính chất cả 2 yếu tố trầm tích lục địa và biển với đường bờ luôn luôn thay đổi.

Trầm tích ở bờ biển phụ thuộc vào loại vật liệu và khối lượng từ nguồn bào mòn vận chuyển đến. Trầm tích lớn nhất diễn ra ở cửa các con sông rộng lớn, ngược lại thể tích trầm đọng diễn ra trong khu vực châu thổ.

Mỗi môi trường lắng đọng tạo nên các chu kỳ trầm tích mang đặc trưng riêng về hình thái, cấu trúc và số lượng các lớp trầm tích.

Những yếu tố cơ bản liên quan đến quá trình thành tạo châu thổ gồm: 
- Quá trình trầm tích, khối lượng trầm tích, tốc độ và diện tích lắng đọng, sự thoát nước;

- Tính chất, thành phần và nồng độ của nước;

- Tốc độ sóng, dòng chảy và thủy triều;

- Độ sâu đáy;

- Tính chất đá gốc nơi dòng chảy đi qua;

- Kiểu cấu trúc bể trầm tích.

\subsection{Tính chất thủy động lực của châu thổ}

Kết quả nghiên cứu về sự hình thành châu thổ của Bates (1953) có đóng góp quan trọng, giúp xác định quá trình phân

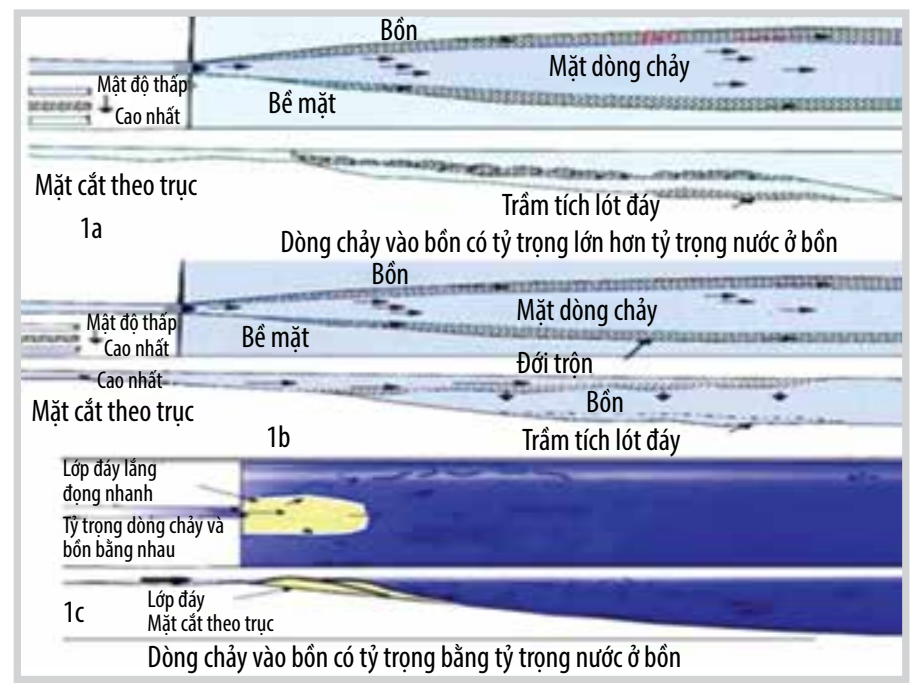

Hình 1. Minh họa các khái niệm dòng chảy ở hạ lưu của sông (Bates, 1953).

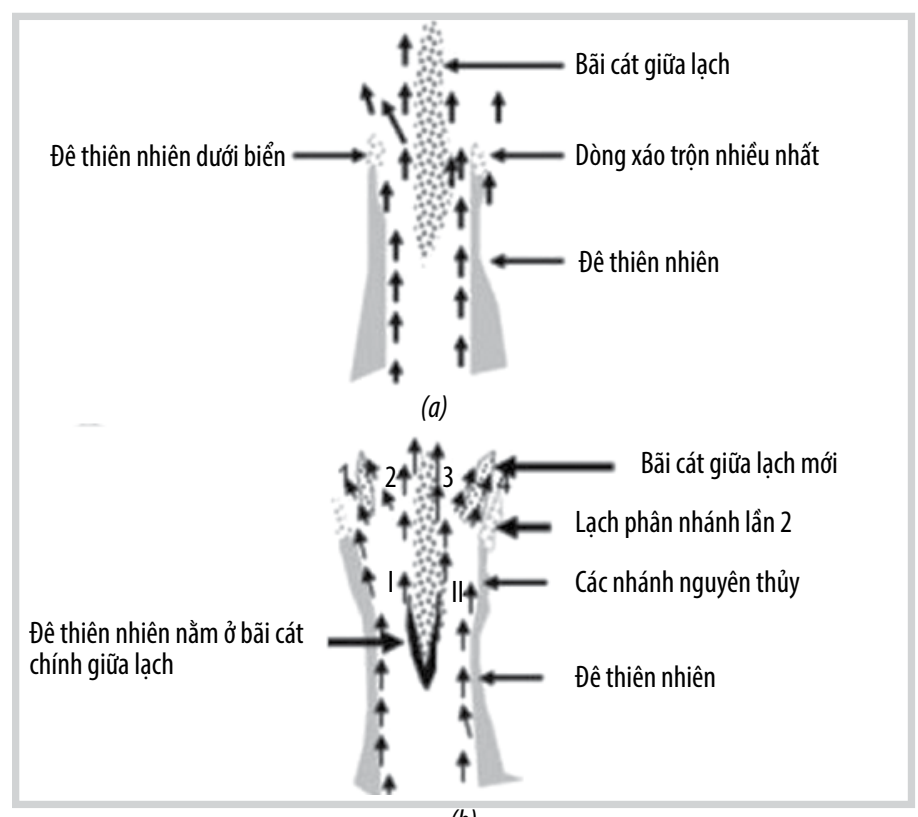

(b)

Hình 2. Minh họa quá trình phân nhánh và thành tạo các thân cát ở cửa sông: Phân nhánh và thành tạo chắn cát lần thứ nhất của sông ở phân hạ nguồn (a); Phân nhánh của sông và các chăn cát tiếp theo ở phân hạ nguồn (b). tán và lắng đọng các trầm tích trong điều kiện tự nhiên. Bates đã đề cập đến các tính chất của dòng chảy, nước chứa phù sa chảy vào vùng nước tĩnh. Dòng chảy tự do này có thể là dòng trục hoặc dòng phẳng.

Đối với dòng là sông ngòi chảy vào vùng nước tương đối yên tĩnh có thể có 3 kiểu dòng chảy (Hình 1):

- Dòng chảy rất đục, có tỷ trọng lớn: Đây thường là dòng sông băng giá chảy vào hồ nước ấm hơn, chế độ chảy có thể coi là dòng phẳng (Hình 1a).

- Dòng chảy ít đục, có tỷ trọng nhỏ hơn: Đây là trường hợp của các dòng sông đổ ra biển, vì có các vật liệu lơ lửng dạng phù sa cho nên nước ở dòng sông thường đục hơn nước biển (Hình 1b).

- Dòng chảy đục vừa phải: Đây là dòng sông chảy vào hồ nước nhạt, chế độ dòng chảy là dòng trục, quá trình hòa hợp nước xảy ra theo 3 chiều. Trầm tích của các dòng chảy này đã tạo thành các châu thổ kiểu đầm hồ (Hình 1c).

\subsection{Chắn cát ở cửa sông, quá trình phát triển và thoái hóa của các phụ lưu}

Sự thoái hóa và phân nhánh là tính chất đặc trưng và quan trọng của quá trình thành tạo châu thổ.

Quá trình phân nhánh và tạo các chắn cát ở cửa sông được thể hiện trên Hình 2.

- Pha tạo nhánh đầu tiên (Hình 2a): Dòng sông chảy về hạ nguồn, tạo bãi cát giữa dòng, dòng chảy phân thành 2 nhánh chảy sang 2 bên đụn cát với các đê nâng cao tự nhiên 2 bên bờ sông.

- Pha tạo nhánh tiếp theo (Hình 2b): Có sự thay đổi lưu lượng cũng như khối lượng vật liệu chuyển tải về hạ nguồn; hình thành các bãi cát ở giữa các lạch, các nhánh sông lại bắt đầu phân nhánh và tạo nên những cồn cát nối tiếp liên tục ở hạ nguồn. Các cồn cát ở cửa sông có dạng hình thoi, lưỡi liềm với kích cỡ khác nhau. Nơi đây sẽ dần dần hình thành châu thổ.

\subsection{Chu kỳ thành tạo châu thổ}

Quá trình hình thành chắn cát ở cửa sông qua 3 giai đoạn, được mô tả tổng thể qua bình đồ và mặt cắt (Hình 3). Dòng chảy luôn luôn có xu hướng đổi dòng thậm chí muốn phá vỡ cả bờ đê để duy trì tốc độ chảy lớn nhất; các đê ngập nước thường tiếp nối với các doi cát và phát triển mạnh. 


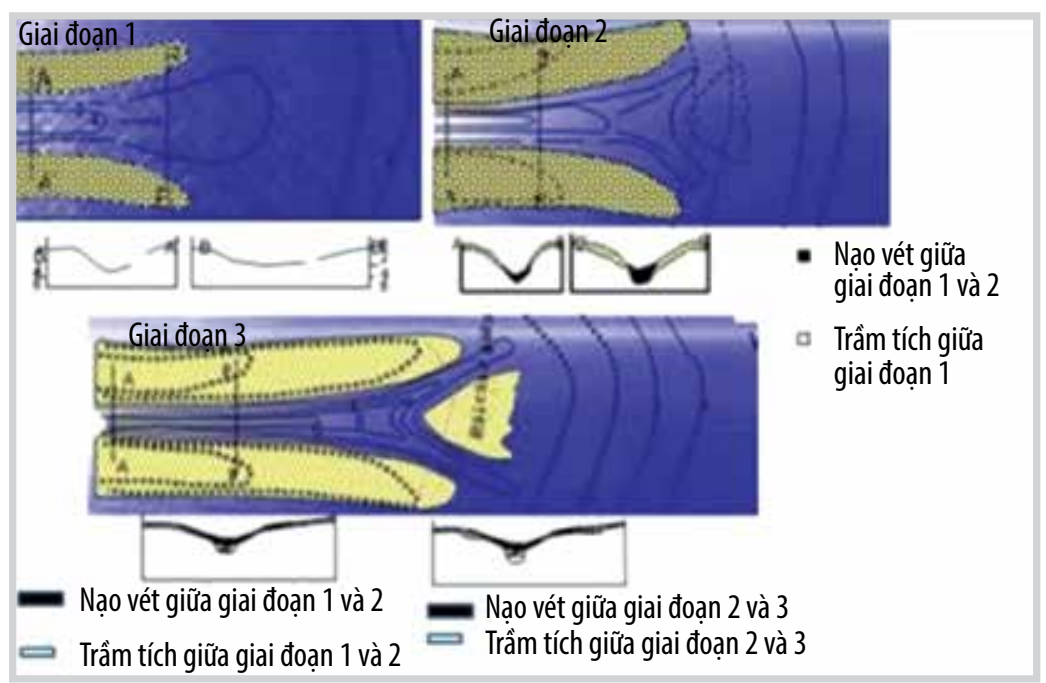

Hình 3. Các giai đoạn thành tạo châu thổ trên bình đồ và mặt cắt.

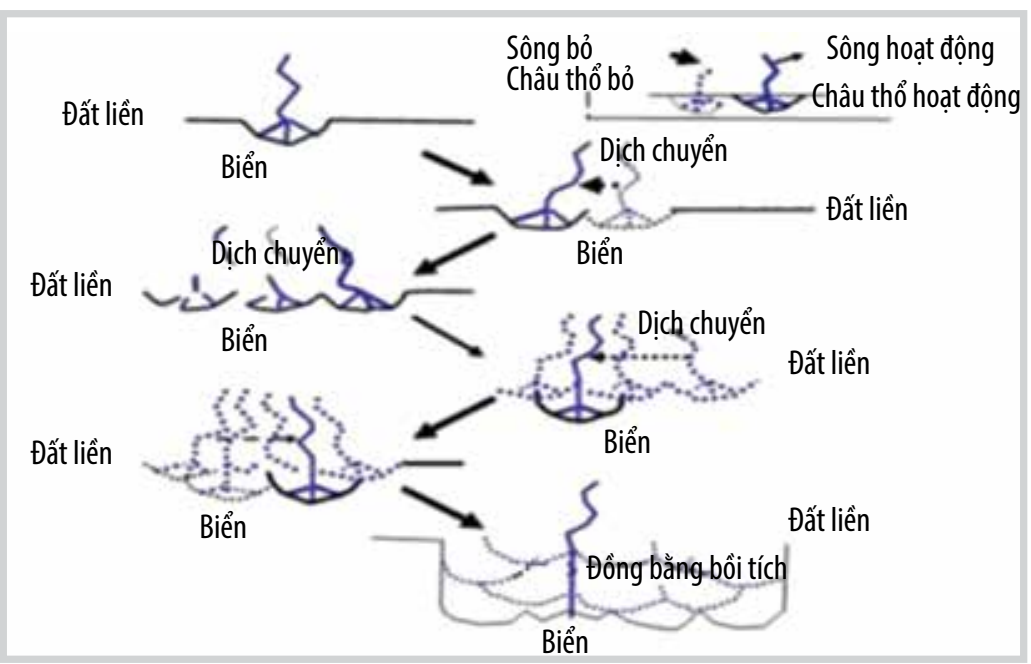

Hình 4. Quá trình dịch chuyển và thành tạo các châu thổ mới của hệ thống sông.

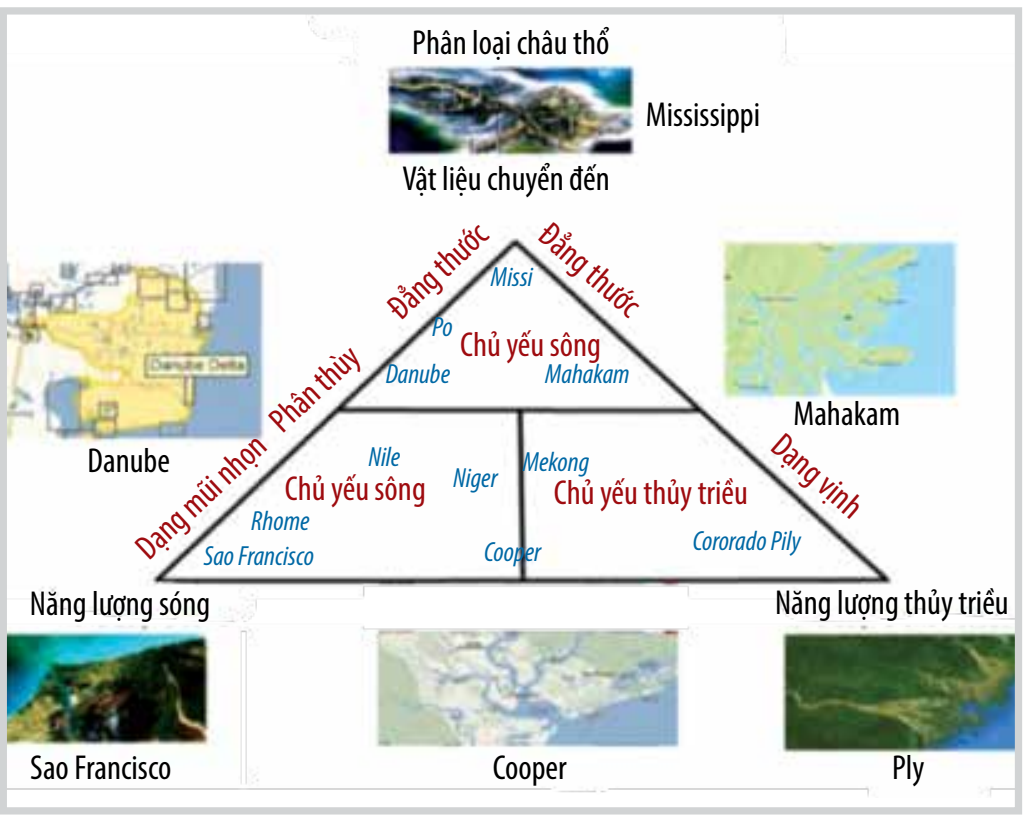

Hình 5. Phân loại các châu thổ theo tác động của các dòng chảy chi phối vật liệu trầm tích.
Trong hệ châu thổ, các tướng sông, hoặc ảnh hưởng của sông, được coi là tướng bồi đắp - đây chính là sản phẩm của sự bồi tích và lấn biển trong quá trình thành tạo châu thổ.

Quá trình hình thành châu thổ, quá trình bỏ và dịch chuyển của hệ thống sông và thành tạo các châu thổ bồi đắp mới thể hiện (Hình 4).

\section{Phân loại châu thổ}

Biểu đồ tam giác phân loại các kiểu châu thổ điển hình trên thế giới dựa trên các yếu tố năng lượng dòng chảy: dòng chảy của sông, sóng và thủy triều (Hình 5).

- Những châu thổ được hình thành chủ yếu bởi trầm tích do quá trình phát triển của sông được coi là những hệ châu thổ bồi đắp mạnh. Những châu thổ này có dạng đẳng thước như châu thổ Mississippi dạng chân chim. Các châu thổ hình thành chủ yếu do sông và sóng, như châu thổ sông Danube, là đồng bằng bồi tích, thường có dạng phân thùy. Ngược lại, có châu thổ chịu ảnh hưởng của sông và thủy triều như châu thổ Makaham, ở phần đồng bằng châu thổ gặp nhiều vịnh, hồ.

- Những châu thổ được thành tạo bởi các quá trình trầm tích chịu ảnh hưởng chủ yếu của quá trình tạo biển được coi là hệ châu thổ phá hủy. Các châu thổ bị phá hủy được hình thành chủ yếu do thủy triều, tạo nên nhiều vũng vịnh, đầm phá như châu thổ Fly, Cooper. Ngược lại, có châu thổ khá bền vững, được hình thành chủ yếu do sóng như châu thổ Sao Francisco.

Trong phạm vi châu thổ, các trầm tích hạt mịn lắng đọng ở đầm nước rộng lớn hoặc hình thành các bãi thủy triều làm thoái hóa các doi cát thủy triều. Điển hình các châu thổ phá hủy mạnh như Irrawaddy, Mekong, Fragier, các châu thổ ở vịnh Papua và ở vùng ven biển Đông Á. Các tướng trầm tích châu thổ được thành tạo từ sự tương tác của các quá trình cơ học như sóng, chế độ thủy triều, dòng chảy và khí hậu với hoạt động vận chuyển trầm tích của các dòng 


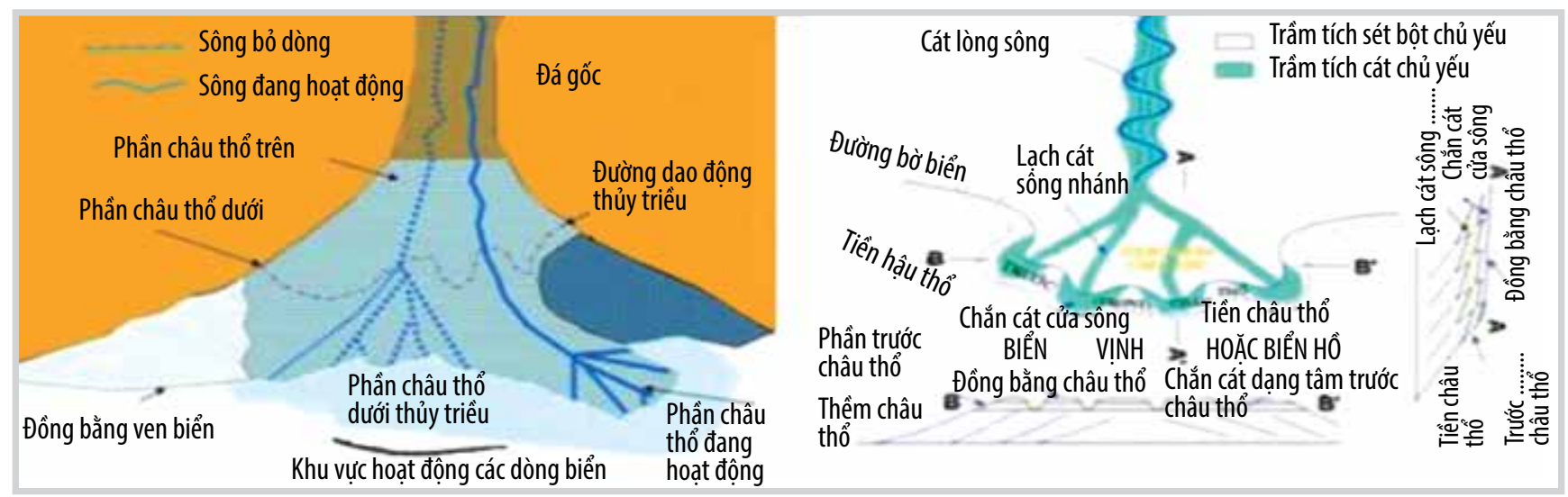

Hình 6. Minh họa ý tưởng về các mô hình phân chia các khu vực trầm tích về châu thổ: Hình thái về các môi trường lắng đọng trâm tích theo J.M. Coleman và D.B.Pior (a); theo Pettijonh (b).

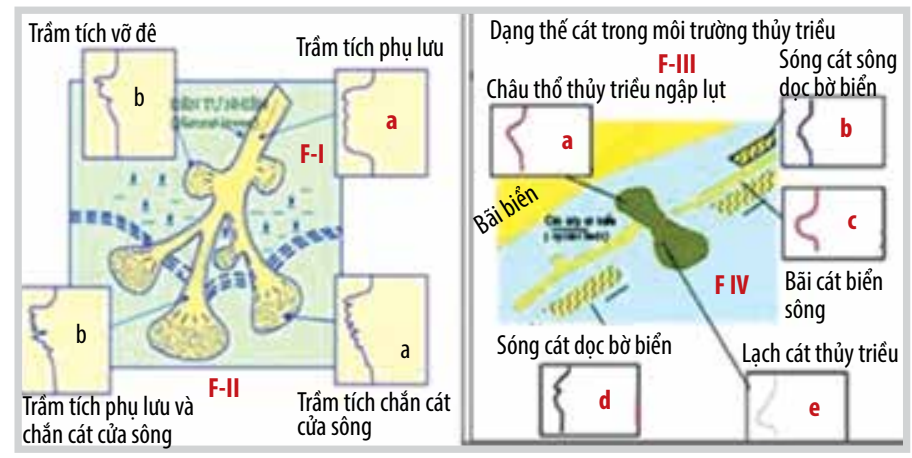

Hình 7. Các dạng đường cong SP\&GR đặc trưng các thể cát trong các môi trường biển nông và thủy triều Lô 07/3 và 04-1 bể Nam Côn Sơn.

sông. J.M. Coleman và D.B. Pior đã minh họa ý tưởng về các mô hình phân loại các khu vực trầm tích châu thổ (Hình 6). Theo Pettijonh (1972), châu thổ bao gồm châu thổ dưới biển sâu hay gọi là tiền châu thổ, phần trước châu thổ hay còn gọi trán châu thổ, rìa châu thổ và bình nguyên châu thổ. Trong đó, các tác giả cho rằng đồng bằng châu thổ có thể phân chia thành đồng bằng châu thổ trên và đồng bằng châu thổ ngập với ranh giới được đánh dấu theo đường thủy triều lên cao nhất.

Các trình tự trầm tích cát kết trong châu thổ cổ được mô tả tiếp theo cùng các kết quả phân tích mẫu lõi, cổ sinh, địa vật lý giếng khoan.

\section{Môi trường trầm tích châu thổ bể Nam Côn Sơn}

Phức hệ trầm tích châu thổ bể Nam Côn Sơn được quan sát tỉ mỉ qua sự thay đổi cả về trầm tích cũng như hóa đá ở giếng khoan CS-1X, Lô 07/3 và các giếng khoan Lô 04-1.

Châu thổ thủy triều hình thành trên cả khu vực chịu tác động mạnh mẽ của thủy triều và các dòng chảy khác. Tất cả được quan sát qua mẫu lõi với sự thay đổi mực nước và tái hoạt động vận chuyển vật liệu, bào mòn của nước mặn trong suốt quá trình vận chuyển từ các dòng nước ngọt vào nước lợ và nước biển.

Có 4 kiểu tướng - môi trường trầm tích - được minh giải qua các mẫu lõi, mẫu vụn, vi cổ sinh, thạch học lát mỏng, các chỉ tiêu về độ hạt, tài liệu phân tích môi trường trầm tích từ các dạng đường SP\&GR của các giếng khoan ở Lô 07/03 và Lô 04-1 (PVEP). Các tướng này được mô tả tuần tự từ đồng bằng châu thổ, trước châu thổ, tiền châu thổ và đường bờ biển. Các dạng đường cong SP\&GR đặc trưng các thể cát trong các môi trường trầm tích biển nông và đồng bằng thủy triều Lô $07 / 03$ và 04-1, bể Nam Côn Sơn (Hình 7).

\section{1. Đồng bằng châu thổ thủy triều}

Châu thổ chịu ảnh hưởng và tác động mạnh mẽ của thủy triều. ở khu vực này có sự giao thoa giữa các dòng chảy nước ngọt, nước lợ và nước mặn. Trong khoảng chiều sâu mẫu lõi giếng khoan CS-1X, môi trường trầm tích được mô tả với sự pha trộn và đào khoét của các kênh rạch và dòng chảy của các phụ lưu thủy triều và các đặc trưng của chắn cát ở các cửa phụ lưu. Sự xuất hiện của các tấm sét kết kích thước lớn, hình dạng khác nhau bên trong mẫu đã minh chứng có sự bào mòn, dập vỡ mạnh mẽ trong khu vực đồng bằng châu thổ thủy triều.

\subsection{1. Đặc trưng các thành tạo cát kết chứa dâu khí} trong đồng bằng châu thổ thủy triêu

Các trầm tích giàu cát có khả năng chứa trong các châu thổ thủy triều có thể phát triển rộng nhưng sẽ bị giới hạn phụ thuộc vào tỷ lệ khu vực châu thổ. Trong khu vực sông Fly ở Papua New Guinea, đồng bằng thủy triều mở rộng khoảng $2-5 \mathrm{~km}$ gần sông đến vùng chuyển tiếp giữa biển và đất liền, trên dưới 25 - $35 \mathrm{~km}$ theo chiều rộng ở khu vực gần biển nhất (Mark Radomski, 2014). Các lòng kênh lạch và chắn cát ở khu vực châu thổ thủy triều giàu trầm tích cát, có độ chứa tốt đến rất tốt. Tỷ lệ nhỏ trầm tích sét xuất hiện trong các thành tạo cát tạo nên sự phân lớp xiên không đồng nhất. Sự xuất hiện các cấu trúc xiên trong 
các thành tạo cát do sự giao thoa giữa các dòng chảy, sự lên xuống của thủy triều, dòng chảy phụ lưu sông, hoặc các dòng chảy rối.

Hình 8 minh họa mẫu lõi giếng khoan CS-1X, Lô 07/03, bể Nam Côn Sơn, cho thấy đặc trưng của vật liệu trầm tích lắng đọng đồng bằng thủy triều. Độ sâu mẫu 2.586,6 m: cát kết hạt nhỏ - thô, phân lớp dạng sóng, hạt nhỏ lắng đọng trong khu vực thủy triều hoặc kênh lạch trong khu vực đồng bằng thủy triều. Mũi tên màu xanh chỉ các thành tạo sét dạng vụn tròn do thủy triều lên xuống tạo nên. Độ sâu mẫu 2.623,3 $\mathrm{m}$ : cát kết hạt trung phần dưới của lạch thủy, các lớp sét đen mỏng (mũi tên đỏ), phân lớp dạng sóng minh chứng do ảnh hưởng của sóng và lên xuống của thủy triều. Độ sâu mẫu 2.708,5 m: cát kết hạt trung đồng nhất, xen kẽ các lớp sét kết mỏng (mũi tên màu đỏ), phần trên chứa nhiều mảnh vụn sét trong cát kết (mũi tên xanh) minh chứng vật liệu được tái lắng đọng do dòng chảy thủy triều, vết đào khoét của Planolites.

\subsubsection{Minh giải môi trường trầm tích theo tài liệu phân} tích địa vật lý giếng khoan, mẫu, độ hạt, thạch học lát mỏng

Các mô hình chuẩn đường GR trên Bảng 1 được áp dụng nghiên cứu và minh giải môi trường trầm tích lục nguyên ở Lô 04-1. Hình dạng của các thể cát trong các môi trường khác nhau đều có đặc trưng riêng. Đi từ trầm tích môi trường sông ngòi, tam giác châu đến môi trường biển nông và biển sâu hình dạng của các thể cát sẽ thay đổi (Hình 8).
- Các thể cát kết trong mặt cắt hệ tầng Dừa, Lô 04-1, được lắng đọng trong các môi trường biển nông (mô hình đường $\mathrm{GR}$ đặc trưng dạng F-IIld ở giếng khoan SDN-1RX với thành phần thạch học chủ yếu sét - bột - cát kết, chịu ảnh hưởng thủy triêu).

Khu vực đồng bằng ven biển mô hình đường $G R$ đặc trưng dạng F-Illc; thành phần thạch học chủ yếu là cát xen sét kết lắng đọng trong đồng bằng thủy triều.

- Mô hình đường GR đặc trưng dạng F-llle, trầm tích lắng đọng vùng biển nông, khu vực ảnh hưởng thủy triều, thành phần thạch học chủ yếu cát - bột - sét kết kích thước hạt giảm về phía trên trình tự trầm tích.

- Dạng đường GR có dạng F-IV, dạng chữ $U$ nằm ngang đặc trưng bãi chắn cát ở biển nông, khu vực ảnh hưởng thủy triều của sông (Hình 9).

Mẫu lõi giếng khoan ST-2X, được lấy từ độ sâu 2.569 2.573,8 m trong hệ tầng Thông - Mãng Cầu tuổi Miocene giữa (Hình 10). Cát kết trong đoạn này có độ hạt từ rất mịn đến mịn với độ chọn lọc và mài tròn khá tốt.

Cát kết có cấu trúc phần lớn là song song đôi khi gợn sóng. Đôi khi có các lớp sét mỏng chứa mica và mảnh cây/lignite xen
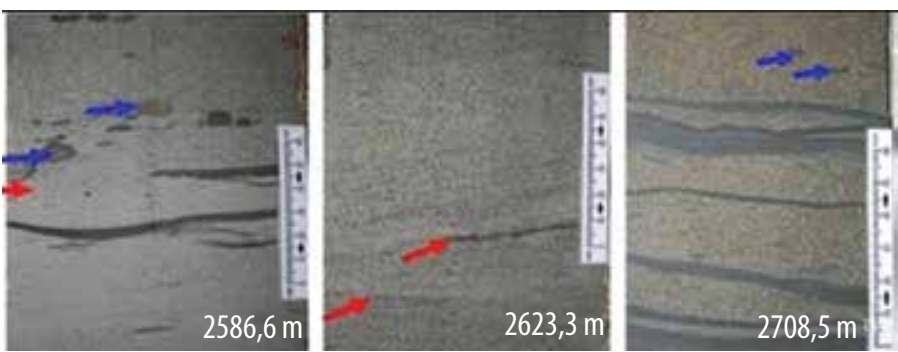

Hình 8. Minh họa đoạn mẫu giếng khoan CS-1X, bể Nam Côn Sơn.

Bảng 1. Thống kê các thể cát qua phân tích đường GR và môi trường trầm tích Miocene dưới - giữa

\begin{tabular}{|c|c|c|c|c|c|}
\hline $\begin{array}{c}\text { Phân loại } \\
\text { theo đường GR }\end{array}$ & Mô hình đặc trưng theo GR & Tướng thạch học & Kiểu trình tự & Môi trường & Giếng khoan \\
\hline F-IIle & 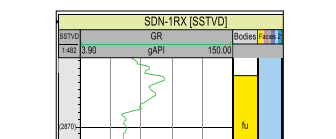 & Cát - bột - sét kết & $\begin{array}{l}\text { Độ hạt giảm dần về } \\
\text { phía trên }\end{array}$ & $\begin{array}{l}\text { Biển nông, khu vực ảnh } \\
\text { hưởng thủy triêuu }\end{array}$ & SDN-1RX \\
\hline F-IIId & 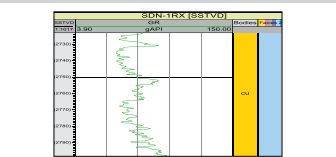 & Sét - bột - cát kết & $\begin{array}{l}\text { Độ hạt tăng dần về } \\
\text { phía trên }\end{array}$ & $\begin{array}{c}\text { Biển nông, khu vực ảnh } \\
\text { hưởng thủy triều }\end{array}$ & SDN-1RX \\
\hline F-IIIC & 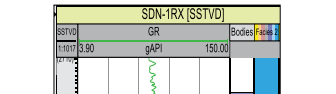 & $\begin{array}{c}\text { Cát xen sét kết dạng } \\
\text { nqón tay }\end{array}$ & & Đồng bằng thủy triều & SDN-1RX \\
\hline F-IV & 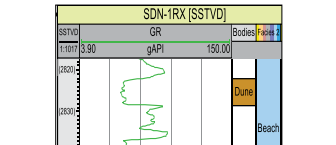 & Cát kết & Dạng khối & $\begin{array}{c}\text { Biển nông đập chắn cát } \\
\text { dọc bờ biển }\end{array}$ & SDN-1RX \\
\hline
\end{tabular}




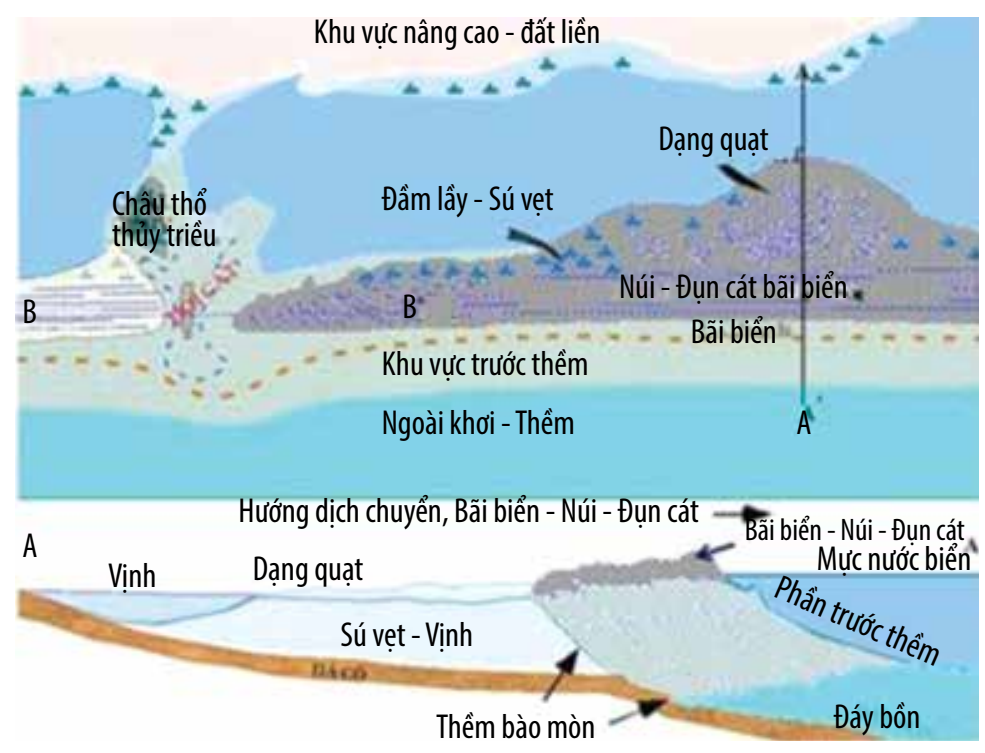

Hinh 9. Các môi trường chính trong khu vực trầm tích biển nông trong thời kỳ thành tạo các thể cát dạng đập chắn, hệ tầng Dừa, Thông - Mãng Cầu tuổi Miocene, Lô 04-1 và Lô 07-03, bểNam Côn Sơn.

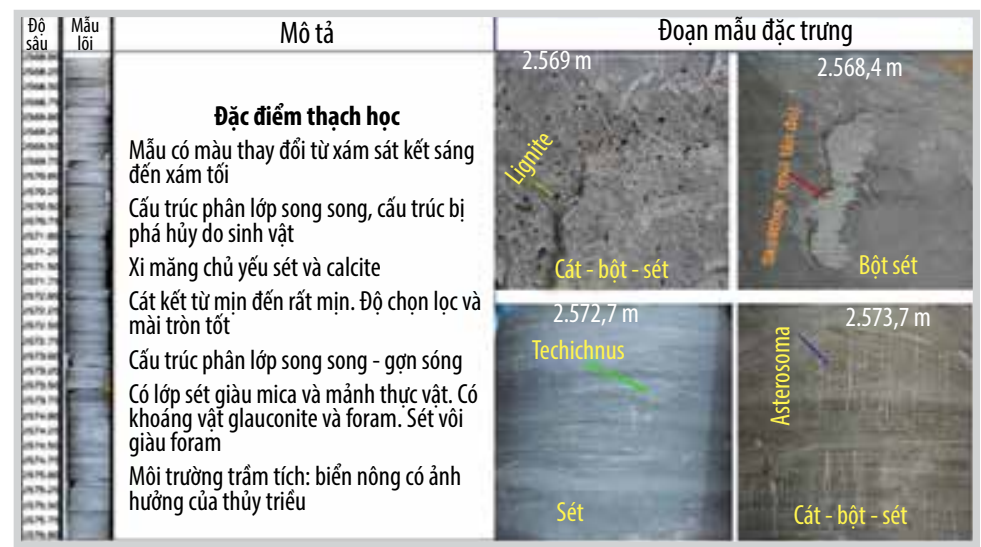

Hình 10. Minh họa đoạn mẫu giếng khoan ST-2X, Lô 04-1, bểNam Côn Sơn (VPI, 2012).

kẹp song song với tập cát này. Rải rác trong đoạn mẫu lõi này có sự xuất hiện của glauconite và foram. Ngoài ra, cấu trúc của đá đôi khi bị phá hủy do hoạt động của sinh vật. Vết sinh vật như Planolites, Teichichnus, Asterosoma và Skolithos được quan sát thấy. Sét trong đoạn này phản ứng mạnh với $\mathrm{HCl} 10 \%$, sét chứa nhiều mảnh foram và hạt vụn tính cỡ bột. Từ tính chất trên có thể thấy rằng vật liệu trầm tích của đoạn mẫu lõi này đã được vận chuyển với dòng chảy năng lượng tương đối thấp. Ngoài ra, sự hiện diện của các vết sinh vật như Planolites, Teichichnus, Asterosoma và Skolithos là những dấu vết của sinh vật sống trong môi trường biển và môi trường nước lợ. Sự hiện diện của mảnh cây/lignite trong đoạn mẫu lõi này có thể kết luận rằng môi trường trầm tích của đoạn mẫu lôi này là biển nông, nơi có ảnh hưởng của hoạt động thủy triều.

Kết quả nghiên cứu các tham số độ hạt liên quan đến năng lượng dòng chảy và sóng giếng khoan ST-2X được minh giải.

Độ hạt của cát kết trong khoảng độ sâu nghiên cứu chủ yếu là hạt rất mịn đến mịn với thông số độ hạt trung bình từ 0,07-0,24 mm. Độ chọn lọc $(\sigma 1)$ của cát kết từ trung bình tốt đến tốt với giá trị $(\sigma 1)$ từ 0,36 đến 0,64 . Độ lệch (SK1) có giá trị âm, từ $-0,06$ đến $-0,85$, điều này chứng tỏ kích cỡ hạt phổ biến (Mo) lớn hơn kích thước hạt trung bình. Độ nhọn $(\mathrm{Kg})$ của đường cong phân bố kích thước hạt hầu hết có dạng leptokurtic (hiếm gặp dạng mesokurtic) với giá trị $\mathrm{Kg}$ từ 0,98 đến 1,29 , cho thấy các hạt tập trung tại trung tâm của đường cong phân bố. Độ mài tròn của các hạt vụn khá tốt với hình dáng hạt phần lớn là bán góc cạnh đến bán tròn cạnh và tròn cạnh. Kết quả phân tích thạch học chi tiết cho thấy cát kết được phân loại chủ yếu là subarkose, rất hiếm cát kết lithic arkose và feldspathic greywacke.

Hình 11 là ảnh lát mỏng mẫu lõi và mẫu vụn giếng khoan ST-2X, Lô 04-1.

Thạch anh: Chiếm khoảng 10,3 - 57,7\%, chủ yếu là thạch anh đơn tinh thể. Vài hạt thạch anh chứa bao thể apatite, zircon và tourmaline.

Feldspar: K-feldspar phổ biến khoảng 3 $5 \%$, còn plagioclase phổ biến khoảng $2-3 \%$. K-feldspar chủ yếu là orthoclase và microcline. Plagioclase có cấu tạo song tinh. Các hạt feldspar chủ yếu bị thay thế bởi calcite và sericite khoảng 1 - 2\%. Mica phần lớn là muscovite.

Mảnh đá: Mảnh đá chiếm một lượng nhỏ gồm các loại mảnh đá granite có vết $-1,7 \%$; mảnh đá phun trào: vết $-5,7 \%$; mảnh đá sét: vết $-3 \%$; mảnh đá quartzite: vết $-1 \%$; mảnh đá carbonate: vết -1,3\%.

Glauconite: Phổ biến: 1 - 2\% trong khoảng độ sâu 3.020 - 3.030 m.

Mảnh sinh vật: Phong phú với chủ yếu là foram: 3,7 - 39\%, algae: vết -8,7\%, bryozoan: $2 \%$; spongy: $3 \%$, mullusk: $4 \%$, echinoderm: $3 \%$.

* Khoáng vật phụ: Khoáng vật phụ chủ yếu là apatite, tourmaline và zircon.

* Khoáng vật thứ sinh: Khoáng vật thứ sinh được thành tạo khá mạnh trong giai đoạn sau trầm tích, chiếm tỷ lệ đáng kể là calcite, dolomite, siderite, kaolinite silica, thạch anh thứ sinh. Khoáng vật thứ sinh lấp đầy các lỗ rỗng nguyên sinh.

Pyrite: Trám lỗ rỗng, lấp đầy khoang sinh vật.

Khoáng vật sét chủ yếu là illite và kaolinite, phủ lên hạt vụn làm giảm kích thước của lỗ rỗng. 


\section{2. Đăc tính chứa các thể cát ở khu vực trước châu thổ}

Trong giếng khoan CS-1X (Lô 07-3, bể Nam Côn Sơn), mẫu lõi trước châu thổ chủ yếu là các trầm tích cát kết hạt mịn và sét kết, ngoài ra còn có đá sét dạng phiến được lắng đọng từ các khu vực đồng bằng châu thổ chuyển đến, đặc tính chứa trong các thành tạo cát kết kém.

Hình 12 minh họa đặc trưng trầm tích trước châu thổ trong các đoạn mẫu lõi giếng khoan CS-1X, bể Nam Côn Sơn. Mẫu ở độ sâu 2.588,7 m: Sét kết xen kẽ cát kết hạt nhỏ phân lớp dạng sóng (mũi tên màu đỏ) và dấu vết sinh vật Phycosiphon. Mũi tên xanh chỉ ra trình tự lặp trong khu vực trầm tích trước châu thổ. Mẫu ở độ sâu 2.690,8 m: Cát kết dạng phiến sét kết bị sinh vật đào khoét (mũi tên đỏ). Mức độ đào khoét của sinh vật (Palaeophycus, Thalassinoides Ophiomorpha) tăng lên minh chứng khu vực nước lợ trong khu vực tiền châu thổ. Các hạt Ophiomorpha có thể thấy trong mẫu (mũi tên xanh). Mẫu ở độ sâu 2.697 m: Sét kết xen kẽ cát kết hạt nhỏ phân lớp dạng sóng và các dấu vết đào khoét của sinh vật Phycosiphon (mũi tên xanh). Có sự biến đổi trong quá trình sau trầm tích (mũi tên màu đỏ). Sự có mặt của Ophiomorpha minh chứng trầm tích lắng trong khu vực dao động của nước mặn.

\section{3. Đồng bằng ven biển}

Trong khoảng mẫu lõi giếng khoan CS-1X chứa sản phẩm chính được minh giải trong trình tự trầm tích cát kết có độ hạt thô dần về phía trên, lắng đọng trong môi trường bãi cát ven biển, dọc theo đường bờ từ các vịnh, hồ của châu thổ đang phát triển hoặc châu thổ đã bỏ. Cát kết có độ bào tròn từ trung bình đến tốt. Sự vắng mặt của các cấu trúc phân lớp do dòng thủy triều tạo nên cũng có thể giả thiết rằng khu vực $C S-1 X$ trong thời kỳ này ở châu thổ ngoài ảnh hưởng của thủy triều.

\subsection{1. Đăc tính cát kết chứa dầu khí của trầm tích ven biển}

Các trầm tích ven biển lắng đọng dọc theo phương đường bờ biển. Các thể đá chứa có thể mở rộng sang ngang và tiếp xúc khá rõ theo phương đường bờ cổ. Tính chất chứa của cát kết sẽ giảm dần theo hướng về phía biển cũng như chiều sâu của nước; kích thước hạt giảm dần theo chiều hướng vào đất liền nhưng không còn trầm tích bãi biển cổ.

Hình 13 minh họa các đoạn mẫu lõi thuộc giếng khoan CS-1X, bể Nam Côn Sơn, có đặc trưng của trầm tích cát kết chứa dầu lắng đọng trong môi trường đồng bằng ven biển, biển nông. Mẫu ở độ sâu 2.559,7 m: Cát kết hạt rất nhỏ trung, phân lớp xiên. Cát kết chứa dầu, không rắn chắc,

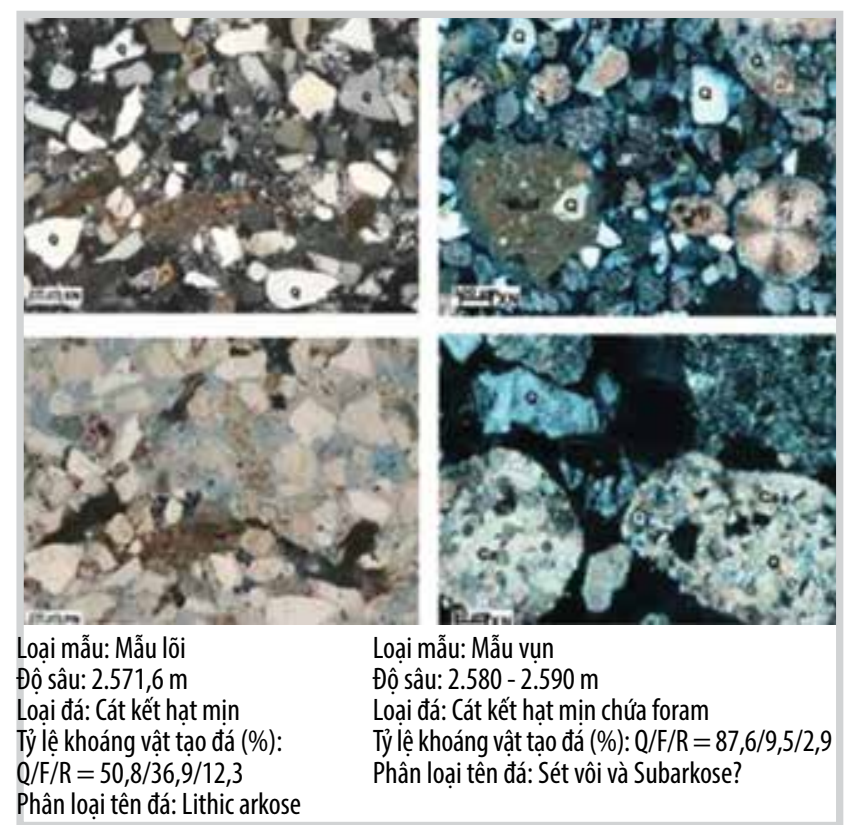

Hình 11. Ảnh lát mỏng giếng khoan ST-2X (VPI, 2012).

có thể nhìn thấy bằng mắt thường (mũi tên vàng). Mẫu ở độ sâu 2.563,7 m: Cát kết hạt trung chứa dầu, dấu vết của Ophiomorpha, Palaeophycus (mũi tên màu đỏ) và dấu vết của Ophiomorpha (mũi tên xanh). Mẫu ở độ sâu $2.568,8 \mathrm{~m}$ : Cát kết hạt trung đồng nhất xen kẽ các lớp sét kết mỏng (mũi tên màu đỏ), phía trên chứa nhiều mảnh vụn sét trong cát kết (mũi tên xanh) minh chứng vật liệu được tái lắng đọng do dòng chảy thủy triêu, vết đào khoét của Planolites.

\subsubsection{Theo các tài liệu phân tích mẫu hệ tâng Thông - Mãng Câu, tuổi Miocene giữa}

Kết quả minh giải sinh địa tầng phân giải cao và cổ môi trường trầm tích của các giếng ST-1X, ST-2X, SDN1RX, hệ tầng Thông - Mãng Cầu, tuổi Miocene giữa, được thực hiện dựa vào kết quả phân tích vi cổ sinh, tảo vôi, bào tử phấn.

4.3.3. Minh giải môi trường trầm tích các thể cát kết theo phân tích địa vật lý giếng khoan

Mặt cắt trầm tích ở các giếng khoan trên cấu tạo sông Tiền, khu vực phía Nam Lô 04-1, cho thấy các trầm tích lục nguyên, xen kẽ các lớp sét vôi trong thời kỳ Miocene giữa.

Các thể cát kết trong mặt cắt hệ tầng Thông - Mãng Cầu, Lô 04-1, được lắng đọng trong các môi trường biển nông dạng sóng cát (F-IIle, F-IIId), lạch cát trong đồng bằng ven biển chịu hoạt động của thủy triều ( $F-I I I C)$, đập chắn cát (F-IV) được minh họa trên Hình 10.

Hình 14 mô tả thành phần thạch học lát mỏng giếng khoan ST-2X. Mảnh vụn có trong khoảng độ sâu này chủ 
yếu là sét vôi, một số mảnh nhỏ cát kết hạt rất mịn và trung bình được gắn kết bởi xi măng sét và xi măng carbonate dạng khảm (10\%), hạt vụn bở rời (55\%), mảnh pyrite (10\%). Sét vôi được cấu thành chủ yếu từ khoáng vật sét trộn lẫn với calcite vi tinh và một lượng nhỏ vật chất hữu cơ.

Một số hạt vụn kích thước cỡ bột như thạch anh và feldspar nổi trên nền sét. Hạt vụn bở rời cỡ hạt mịn, độ chọn lọc tốt, hình dạng từ nửa tròn cạnh đến tròn cạnh, bao gồm chủ yếu là các hạt thạch anh Q (31,3\%), it hat k-feldspar (2,3\%), plagioclase $(2,7 \%)$, mảnh đá phun trào $(1,7 \%)$, mảnh vụn sinh vật foram Fo $(28 \%)$, spongy $(0,7 \%)$. Thạch anh chủ yếu là đơn tinh thể, hiếm thấy thạch anh đa tinh thể; khung sinh vật được thay thế bởi calcite nghèo sắt (nhuộm hồng) và bên trong khoang của sinh vật bị lấp đầy bởi calcite giàu sắt (nhuộm xanh). Các khoáng vật phụ như apatite thường thấy trong hạt thạch anh. Thành phần
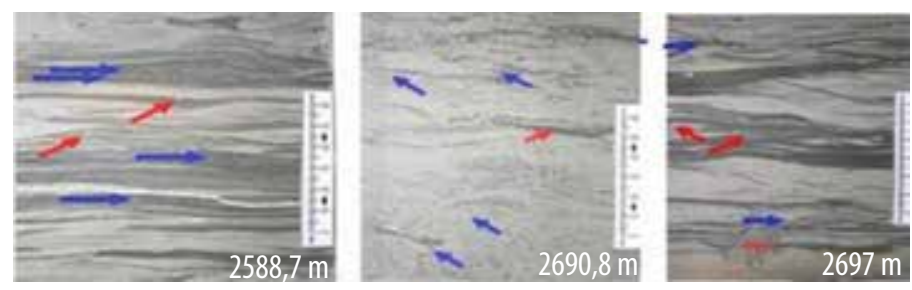

Hình 12. Minh họa các đoạn mẫu lôi, giếng khoan CS-1X, bểNam Côn Sơn, đặc trưng trâm tích trước châu thổ.

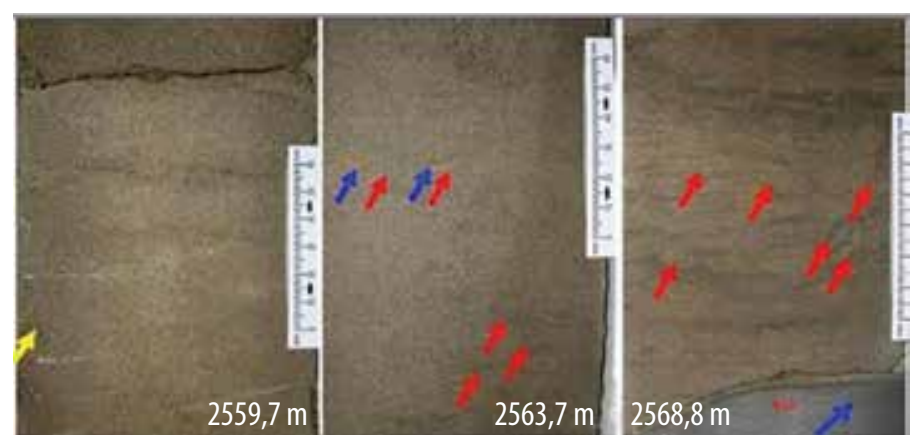

Hình 13. Minh họa đoạn mẫu giếng khoan CS-1X, bểNam Côn Sơn, đặc trưng trầm tích đồng bằng châu thổ. khoáng vật thứ sinh và xi măng chủ yếu là calcite nghèo sắt $(6,3 \%)$, dolomite nghèo sắt $(4,3 \%)$, silica (8\%) và khoáng vật quặng (mũi tên vàng) (14,7\%). Sự hiện diện lượng nhỏ thạch anh thứ sinh phát triển trên hạt vụn thạch anh.

\subsection{Trầm tích khu vực tiền châu thổ}

Khu vực tiền châu thổ chủ yếu là khu vực trầm tích trong biển chịu tác động các dòng vận chuyển của sóng ngầm và bão. Trầm tích trong khu vực là các thành tạo cát hạt mịn, bột, sét lắng đọng cũng có thể theo chiều sâu cột nước hoặc theo trọng lực, từ các môi trường nước nông khác, đặc biệt trong khu vực chuyển tải phù sa lớn của hệ thống sông/đồng bằng ngập. Các trầm tích do trọng lực thường có độ dày mỏng sắc cạnh bên dưới, cát kết rất mịn đến sét phân lớp được vận chuyển từ các dòng (hyperpycnal) hỗn hợp của nước ngọt và nước lợ từ đồng bằng châu thổ. Sự có mặt dòng chảy loại hỗn hợp được minh chứng bởi sự có mặt loại vụn vỡ của các lớp sét và cát kết hạt rất nhỏ.

\subsection{1. Đặc tính cát kết của trầm tích tiền châu thổ}

Trong giếng khoan CS-1X khu vực môi trường tiền châu thổ này không có thành tạo cát kết chứa dầu khí, trong mẫu cũng có đôi chỗ có sét - bột - cát kết nhưng độ thấm, độ rỗng hiệu dụng kém. Mẫu ở độ sâu 2.542,5 m: Cát kết hạt rất nhỏ xen bột kết phân lớp mỏng và sét kết phân lớp gợn sóng (mũi tên đỏ) minh chứng trầm tích được lắng đọng trong môi trường có dòng chảy nước ngọt dạng hyperpycnal của dòng sông với giai đoạn ngập lụt trên khu vực trước châu thổ. Hình 15 minh họa các đoạn mẫu lõi, giếng khoan CS-1X, bể Nam Côn Sơn với đặc trưng trầm tích tiền châu thổ ven biển, biển nông.

Bảng 2. Tóm tắt kết quả nghiên cứu môi trường lắng đọng trầm tích theo tài liệu cổ sinh (VPI)

\begin{tabular}{|c|c|c|c|}
\hline Giếng khoan & Độ sâu (m) & Đới cổ sinh & Môi trường trầm tích \\
\hline ST-1X & $3.030-3.795$ & $\begin{array}{l}\text { N9 } 14 \text { (F)? Đới thực vật Flors. levipoli (P): } 3.732 \text { - } 3.885 \text { m; } \\
\text { Phụ đới Flors. semilobata (P) }\end{array}$ & Biển nông giữa thềm - ngoài thềm \\
\hline ST-2X & $3.030-3.795$ & $\begin{array}{c}\text { N13-N14: } 2.970-2.990 \mathrm{~m}(\mathrm{~F}) \\
\text { N9-N12: } 2.990-3.795 \mathrm{~m}(\mathrm{~F}) \\
\text { NN7: } 3.030-3.190 \mathrm{~m}(\mathrm{~N}) \text { ? } \\
\text { NN5-NN7: } 3.190-3.795 \mathrm{~m}(\mathrm{~N}) \\
\text { Đới thực vật Flors. meridionalis (P) } \\
\text { Phụ đới Flors. semilobata (P) }\end{array}$ & Biển nông giữa thềm - ngoài thềm \\
\hline SDN-1RX & $1.900-2.502$ & $\begin{array}{c}\text { N13-N14: } 2.970-2.990 \mathrm{~m}(\mathrm{~F}) \\
\text { N9-N12: } 2.990-3.795 \mathrm{~m}(\mathrm{~F}) \\
\text { NN7: 3.030 - 3.190 m (N)? } \\
\text { NN5-NN7: 3.190 - } 3.795 \mathrm{~m}(\mathrm{~N})\end{array}$ & $\begin{array}{c}\text { Biển nông trong thềm - giữa thềm }(1.900 \mathrm{~m}) \text { Biển } \\
\text { nông giữa thềm - ngoài thềm }(2.050 \mathrm{~m}) \text { Biển nông } \\
\text { trong thềm - giữa thềm }(2.085-2.700 \mathrm{~m}) \text { Biển nông } \\
\text { trong thềm }(2.800-2.900 \mathrm{~m})\end{array}$ \\
\hline
\end{tabular}


Bảng 3. Thống kê các thể cát qua phân tích đường GR và môi trường trường trầm tích tuổi Miocene giữa, hệ tầng Thông - Mãng Câu ở các giếng khoan ST-1X, ST-2X và ST-1X.

\begin{tabular}{|c|c|c|c|c|c|}
\hline $\begin{array}{l}\text { Phân loại } \\
\text { theo đường GR }\end{array}$ & $\begin{array}{c}\text { Mô hình đặc trưng } \\
\text { theo GR }\end{array}$ & $\begin{array}{c}\text { Tướng } \\
\text { Thạch học }\end{array}$ & Kiểu trình tự & Môi trường & Giếng khoan \\
\hline F-IIlb & 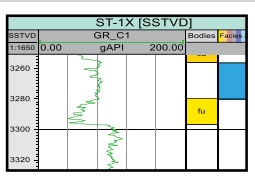 & Cát-bột - sét kết & $\begin{array}{c}\text { Độ hạt giảm dần về } \\
\text { phía trên }\end{array}$ & $\begin{array}{c}\text { Biển nông, khu vực ảnh } \\
\text { hưởng thủy triểu }\end{array}$ & $\begin{array}{l}\text { ST-1X } \\
\text { ST-2X }\end{array}$ \\
\hline F-IIId & 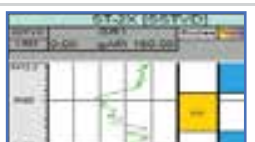 & Sét - bột - cát kết & $\begin{array}{l}\text { Độ hạt tăng dần về } \\
\text { phía trên }\end{array}$ & $\begin{array}{c}\text { Biển nông, khu vực ảnh } \\
\text { hưởng thủy triêuu }\end{array}$ & $\begin{array}{l}\text { ST-1X } \\
\text { ST-2X }\end{array}$ \\
\hline F-IV & 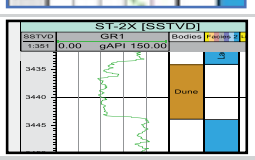 & Cát kết & Dạng khối & $\begin{array}{c}\text { Biển nông } \\
\text { đập chắn cát dọc bờ biển }\end{array}$ & ST-2X \\
\hline
\end{tabular}

Vết tích đào khoét của sinh vật, Planolites (PI) và Scolicia (Scol) thưa thớt. Trầm tích trong đoạn chiều sâu mẫu được lắng đọng trong cả 2 môi trường nước lợ và nước ngọt, trong khu vực tiền châu thổ. Mẫu độ sâu 2.605,2 m: Cát kết hạt rất nhỏ xen bột kết phân lớp mỏng và sét kết phân lớp gợn sóng (mũi tên đỏ) vết tích đào khoét của sinh vật. Schaubcylindrichnus thưa thớt nhưng phía dưới ảnh cột mẫu lại tăng lên, minh chứng trầm tích được lắng đọng môi trường trầm tích biển nước mặn - lợ, trong khu vực tiền châu thổ. Mẫu ở độ sâu 2.725 m: Cát kết hạt rất nhỏ xen bột kết phân lớp mỏng và sét kết màu đen phân lớp gợn sóng môi trường tiền châu thổ, phủ lên trên là cát kết hạt trung lắng đọng trong môi trường đồng bằng châu thổ (mũi tên xanh chỉ ranh giới tiếp xúc).

Mark Radomski phác họa trình tự địa tầng (Hình 16), trình tự vuông góc đường bờ của châu thổ thủy triều dịch chuyển và kế tiếp trong giếng khoan CS-1X. Điều đáng chú ý là trình tự độ hạt tăng về phía trên được đánh dấu bằng mặt bào mòn, bất chỉnh hợp trong khu vực bên dưới là trầm tích tiền châu thổ; sự thay đổi nham tướng theo chiều ngang có thể từ $1 \mathrm{~km}$ đến hàng chục km.

4.4.2. Về thach học trầm tích, các thể cát chứa dầu khí trong các thành tạo ở lưu vực hạ lưu sông và châu thổ ven biển tai khu vức các lô 03, 04-1, 04-3, 05-1b, 05-2 và 07/03 có đăc trưng sau:

- Chắn cát ở cửa sông có phụ lưu hẹp, chảy ra vùng nước nông

+ Độ hạt: Cát kết sạch, chọn lựa tốt ở khu vực trung tâm, cát, bột, sét kết ở trên và dưới.

+ Cấu trúc: Phân lớp ngang mỏng, xiên chéo, chứa các mảnh thực vật, có nhiều thấu kính sét, bột.

+ Tiếp xúc: Khu vực phía trên chuyển tiếp từ từ lên
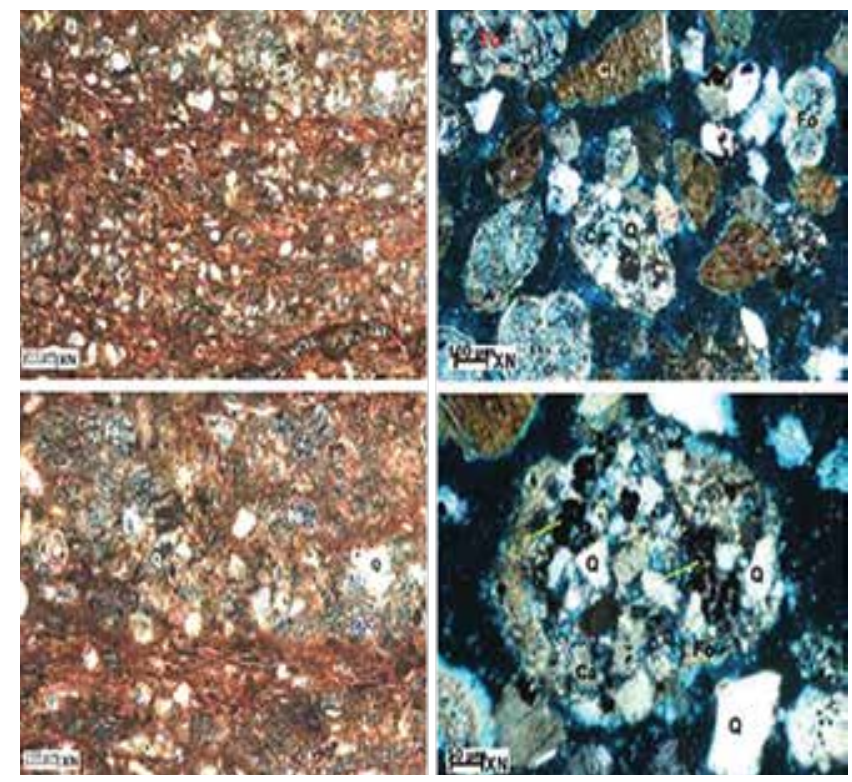

Loại mẫu: Mẫu vun

Độ sâu: 3.660 - $3.670 \mathrm{~m}$ Loai đá: Sét vôi

Tỷ lệ khoáng vật tạo đá (\%)

Tên đá: Sét vôi chứa foram

Loại mẫu: Mẫu vun

Độ sâu: 3.640 - $3.650 \mathrm{~m}$

Loai đá: Cát kết hat min

Tỷ lệ khoáng vật tạo đá (\%): $Q / F / R=82,4 / 13,2 / 4,5$

Tên đá: Subarkose?

Hình 14. Ảnh lát mỏng giếng khoan 04-1-ST-2X (Theo VPI, 2012).

các trầm tích sét vôi đê tự nhiên hoặc vịnh; khu vực phía dưới chuyển tiếp từ từ sang trầm tích trước châu thổ.

+ Kích thước: Có thể phủ hàng trăm mét, độ dày không ổn định.

+ Cổ sinh: Không phổ biến nhưng thường có sự hỗn hợp giữa nước lợ và ngọt.

+ Tầng chứa: Rất tốt.

- Chắn cát ở cửa sông có phụ lưu rộng chảy ra vùng nước sâu

+ Độ hạt: Ở đới trung tâm cát sạch, chọn lựa tốt.

+ Cấu trúc: Phân lớp ngang mỏng, xiên chéo ở trung tâm, phổ biến các mảnh thực vật. 
+ Tiếp xúc: Khu vực phía trên thì trầm tích sét vôi hoặc vịnh tuần tự trong phần đê tự nhiên và không tuần tự ở cận lạch lấp đầy; khu vực phía dưới: tuần tự.

+ Kích thước: Rộng 9,5km, dài 28 m, dày trên 94 m.

+ Cổ sinh: Thỉnh thoảng gặp mảnh sò, vụn thực vật.

+ Tầng chứa: Rất tốt.

- Các đảo cát rìa châu thổ

+ Độ hạt: Cát sạch, chọn lựa tốt ở đỉnh.

+ Cấu trúc: Đặc trưng cấu trúc đụn, đống; phân lớp xiên chéo.

+ Tiếp xúc: Tuần tự, phủ lên trên trầm tích biển nơi sụt lún nhanh. Khu vực phía dưới: Không tuần tự của các trầm tích tiền châu thổ.

+ Kích thước: Độ dày hơn 18 m. Chiều rộng lớn nhất $3,5 \mathrm{~km}$, dài $18 \mathrm{~km}$.

+ Cổ sinh: Cát chứa vết sò.

+ Tầng chứa: Tốt nhất.
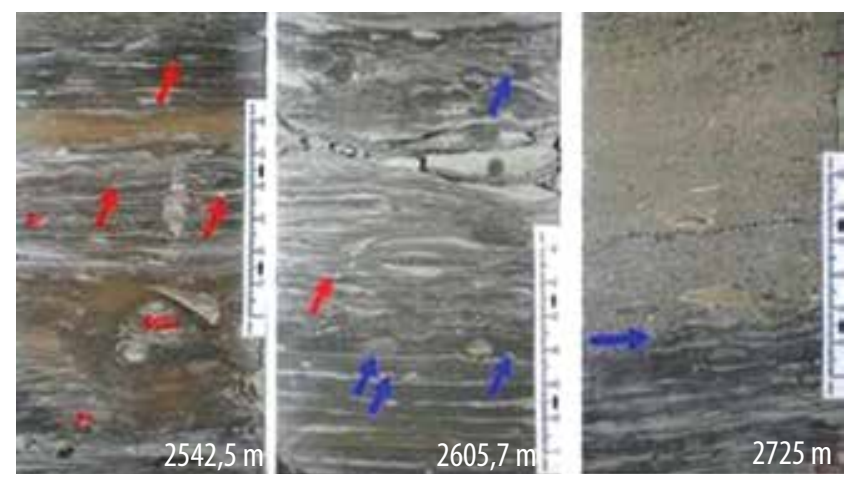

Hinh 15. Minh họa các đoạn mẫu lõi giếng khoan CS-1X, bể Nam Côn Sơn, đặc trưng trầm tích tiền châu thổ.

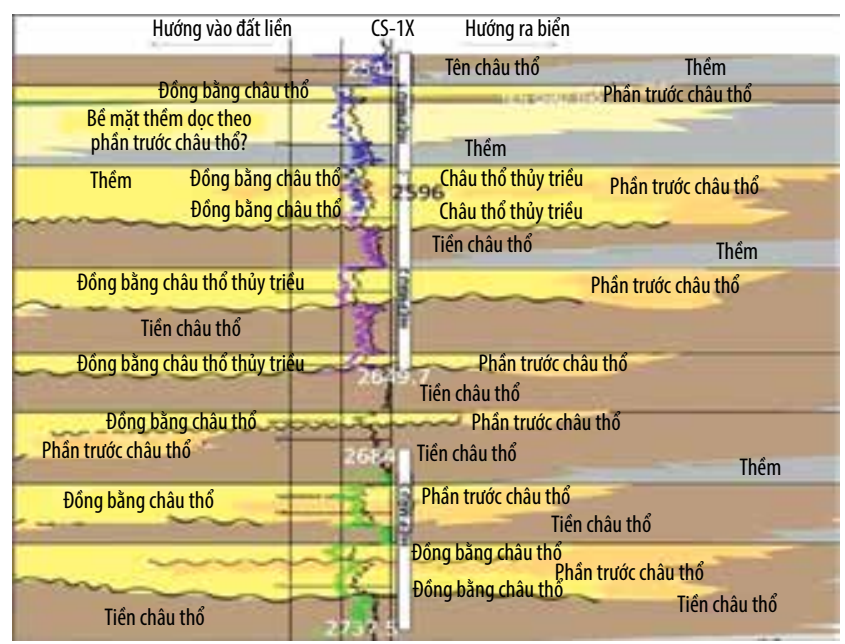

Hình 16. Biểu đồ phác họa trình tự địa tâng vuông góc đường bờ của châu thổ thủy triêu dịch chuyển và kế tiếp trong giếng khoan CS-1X.

\section{Kết luận}

Các môi trường trầm tích trong khu vực châu thổ, dòng chảy của sông và các phụ lưu giữ vai trò chính trong quá trình hình thành trầm tích. Sự phức tạp và đa dạng các tướng, trình tự trầm tích do:

- Mô hình phát triển châu thổ trong một diện rộng lớn, chịu sự tác động của khí hậu, kiến tạo, lún chìm của bồn trầm tích.

- Châu thổ được hình thành ban đầu với sự tác động xen kẽ giữa trầm tích sông và các môi trường ven biển.

- Các trầm tích trong châu thổ, được lấp đầy các trầm tích từ sông mang đến lưu lượng lớn với các thành phần vụn trầm tích có kích cỡ và thành phần khác nhau:Từ bùn, sét, bột, đến các hạt nhỏ và sạn, cuội.

- Sự lún chìm nhanh cùng với bồi đắp với khối lượng vật liệu khổng lồ, tạo nên các trầm tích ở các môi trường trên có diện phân bố rộng và bề dày lớn, chứa nhiều vật liệu hữu cơ. Với kết quả bồi đắp trầm tích trong điều kiện trên, các trầm tích cát thường là đối tượng chứa dầu khí rất tốt. Các trầm tích mịn, chứa nhiều vật chất hữu cơ ở tiền châu thổ là các thành tạo sinh dầu tốt trong bể Nam Côn Sơn.

- Các thể cát kết dọc bờ biển, chắn cát cửa sông là đối tượng tìm kiếm thăm dò quan trọng ở các lô 03, 04-1, 04-3, 05-1b, 05-2, 07/03 ở bể Nam Côn Sơn.

- Cát kết của trầm tích lục nguyên tuổi Miocene là đối tượng chứa tốt đã được chứng minh ở mỏ Đại Hùng, cấu tạo Thanh Long và trong các cấu tạo khác thuộc bể Nam Côn Sơn. Môi trường thành tạo của cát kết ở đây chủ yếu là sông ngòi, ven bờ và biển nông.

\section{Tài liệu tham khảo}

[1] F.J. Pettijohn, Sedimentary rocks, 1972.

[2] J.P. Bertrand, Cours de pétrographie appliquée à l'étude des problèmes pétroliers: Étude des roches. Société des Editions Technip et Institut Français du Pétrole, 1969.

[3] Evert van de Graaff, Sedimentology and depositional environments of deep water deposits, 2014.

[4] Phan Huy Quynh và nnk, "Các phức hệ cổ sinh Các dạng cổ sinh đặc trưng và mối liên quan của chúng tới môi trường trầm tích ở các bồn trũng trầm tích Đệ Tam Việt Nam", Hà Nội, 1995.

[5] Luca Cosetino, Intergrated reservoir studies. IFP, 2007 
[6] Nguyễn Du Hưng và nnk, "Báo cáo tính trữ lượng dầu khímỏ Đại Hùng", 2005.

[7] Marek Kacewicz, ETC, Vietnam basin modeling, Chevron, 2007.

[8] Octanvian Cantuneanu, Principles of sequence stratigraphy. Department of Earth and Admospheric Siences University of Alberta, 2006.

[9] Peter A.Scholle and Darwin Spearing, "Sandstone depositional environments", American Association of Petroleum Geologists, Vol. 31, 1980. DOI: 10.1306/M31424.

[10] Roger M. Slatt, Stratigraphic reservoir characterization for petroleum geologists, geophysicists and engineers. University of Oklahoma, 2006.

[11] Robert R. Berg, Reservoir sandstones. Texas AS\&M University, 1986.

[12] Satinder Chopra and Kurt J. Marfurt, Seismic attributes for prospect identification and reservoir characterization, Society of Exploration Geophysicists. DOI: 10.1190/1.9781560801900.

[13] Trần Khắc Tân, Ban Tìm kiếm Thăm dò, PVEP, "Phân tích môi trường lắng đọng trầm tích lục nguyên, các bồn trũng chứa dâu khí ở Việt Nam theo tài liệu đo địa vật lý giếng khoan GR và SP log", 2009 - 2010.

[14] Trần Khắc Tân và nnk, "Đá chứa cát kết và môi trường trầm tích", 2011.

[15] Tran Khac Tan, Nguyen Anh Duc and Pham Hai Dang, "The morphology and depositional environment of the hydrocarbon-bearing sandstones", 2013.

[16] VPI-VSP, "Báo cáo nghiên cứu cổ địa lý tướng đá Lô 04-1 giếng 04-1-ST-2X", 2012.

[17] Phạm Hải Đăng và nnk, "Đánh giá tiềm năng dầu khí của các cấu tạo triển vọng trong Lô 04-1 bồn trũng Nam Côn Sơn", PVEP, 2015.

[18] Mark Radomski, "Sedimentology of the CRD-3X cored interval, Nam Con Son basin, Viet Nam", 2014.

[19] Nguyễn Quang Bô, Lê Văn Trương, Phạm Hồng Quế và nnk, "Cấu trúc địa chất và hệ thống dâu khí bồn trũng Nam Côn Sơn, thềm lục địa Nam Việt Nam", 1995.

[20] Nguyễn Anh Đức và nnk, "Báo cáo đánh giá cơ hội tìm kiếm thăm dò Lô 03- bồn trũng Nam Côn Sơn", 2011.

\title{
DELTAIC ENVIRONMENTS AND RESERVOIR SANDSTONES OF NAM CON SON BASIN
}

\author{
Tran Khac Tan', Ngo Thuong San', Nguyen Manh Toan', Pham Hai Dang², Hoang Thi Thu Trang², Tran Tho² \\ 'Vietnam Petroleum Association \\ 2Petrovietnam Exploration Production Corporation \\ Email: tantk2016@gmail.com
}

\section{Summary}

The shoreline is the transition zone that separates nonmarine processes and environments from marine processes and environments. In this zone, there are both marine and nonmarine influences. Delta is complex bodies of sediments deposited at the river mouths. Its morphology and stratigraphy are dependent on the volume of the river and its drainage area as well as on several other factors such as the sediment load of the topography, and the nature and intensity of nearshore marine processes that act to rework and disperse the sediment once it reaches the coast. Also, sediment can be supplied to the shore zone from offshore and alongshore sources, which are unrelated to a river.

Deltaic sandtones play as an important reservoir for oil and gas in many basins around the world.

Four major facies and environment types were interpreted using well logs and cores data of wells CS-1X and ST-2X in the Nam Con Son basin. These facies include the delta plain, delta front, shoreface, and pro-delta.

Key words: Sedimentary environment, sandstone, Nam Con Son basin. 